\title{
Poetry and Pandemic: A Study of Two Viral Social-Media Poems during COVID 19 Lockdown
}

\author{
Sreejata Roy \\ PhD scholar, Rabindra Bharati University Kolkata-700050, West Bengal, India \\ Lecturer, Department of English, Jogesh Chandra Chaudhuri College, Kolkata, West Bengal, \\ India \\ Email Id: sreejataroy15@gmail.com
}

\begin{abstract}
The need for poetry and poets in society has been debated since Plato's age. But at no time perhaps, its significance can be questioned as much as it has been during a crisis that demands immediate and concrete solutions and aid, like a pandemic. However, on the contrary, the current coronavirus pandemic necessitating social isolation and countrywide lockdowns has witnessed a sudden surge in the production of 'social-media poetry'. The legitimacy of such poetry has often been debated but their popularity has proved that they are far from irrelevant. This paper intends to study two such viral poems, 'Lockdown' By Richard Hendrick and 'The First Lines of Emails I've Received While Quarantining' by Jessica Salfia. Unlike the poem-posts by popular Instapoets, these unembellished poems are by persons from ordinary walks of life with no aspiration to be a professional or famous. The objective is to explore the kind of sentiments readers are falling for at such an epoch shifting time as this and the new directions such poems indicate for contemporary poetry. The study also emphasizes that poetry as a genre is not just relevant but is perhaps more 'essential' than it has been in recent history in the wake of such viral poetry during the uncertainties of a pandemic.
\end{abstract}

Keywords: Pandemic, Viral, Social Media, Poetry, Covid 19 Poems

Time and again, since Plato's age, poetry as a genre or poets have been accused of being irrelevant and useless. An incendiary 1988 essay by American essayist Joseph Epstein, "Who Killed Poetry?" accuses contemporary poetry of being mediocre and responsible for killing the genre (Epstein ,Web). Another essay by Diana Gioga published three years later, titled "Can Poetry Matter" charged contemporary poetry for being too isolated and invisible (Gioia , Web). Recognized poetry toward the later half of the twentieth century emerged only from professors and students of literature (Wilcox,Web). This phenomenon has been partly checked with the advent of the internet and social media at our fingertips in the twenty-first century. However, it is during a crisis that demands immediate and concrete solutions and aid, like a pandemic when the significance of poetry can be questioned most. Much like humanities as a discipline in modern times, poetry has been perceived to be a luxury more than a necessity. It was perhaps to be relegated to frivolity, something non-essential at a time, when only 'essential' services and products are required. Nevertheless, evidence shows that the demand for poetry has increased in recent pandemic-stricken times. There have been writings about policemen using poems for exercising control or celebrities and even children writing poems on coronavirus or to thank health workers, not to mention the spawning of online poetry writing contests and poetry reading sessions. The world presently reeling under 
the severe and indefatigable coronavirus pandemic, has seen a sudden rise in the circulation of online poetry (Cyril, Web).As the serious levels of the virus' contagiousness shut down the major countries across the world, quarantined millions of people, internet and social media became the only channels of human communication. Hence it is not a surprise that the muchcondescended genre of 'social media poetry', or even poetry circulated online became the primary source for a people hungry for comfort and connection. This paper intends to highlight two such social-media poems not so much to assess their poetic merit but to understand or explore the kind of sentiments readers are falling for at such an epoch shifting time and the new directions they indicate for contemporary poetry. Their significance lies in the fact that despite not being written by any popular 'Instapoet', but by persons from ordinary walks of life, they went 'viral' in the peculiar intersection of the viral pandemic and internet or social media usage. Thus, while emphasizing that the space for poetry is far from saturated, the study also aims to uncover the different older poetic movements with which these electronic-poems resonate. Owing to the nature and context of the topic, this paper relies heavily on news reportages and articles to understand the contemporary circumstances which the poems refer to.

'Social-media poets' or the Instapoets as they are often called were popular on the internet even before the pandemic. These 'poets' amassed wealth publishing collections of their online 'poetry posts' or 'micropoetry' which they write on platforms like Instagram, Twitter, Facebook or Tumblr etc. The most well-known of these poets, RupiKaur's book Milk and Honey (2015) got about 2.5 million copies sold (Mzezewa,Web). Most of these poets go by pen names. Some of the well-known names include Rueben Holmes who goes by the name 'r.h. sin', Atticus, Macius or R.M Drake who became a New York Times Bestselling poet with 1.9 million followers on Instagram (Wallersteiner). These writers focus on commonplace experiences of love and healing (Kaur, Rupi Kaur: 'There was no market for poetry about trauma, abuse and healing'). They pay close attention to the spacing, the page and the colour or presentation of their lines. Proper marketing and sponsorship are essential for popularizing their pages. Many of these posts have been collected and published as books with further additions. An idea about the content of such poetry-posts can be gleaned from two instances of Kaur's posts which run like: "fall/in love/with your solitude" or "you've touched me/without even/touching me (Kaur, Instagram Photo) As Anna Leszkiwicz's article in the New Statesman affirms, the legitimacy and merit of such 'poetry' have often been questioned. Even if these poems are just a pop phenomenon cut off from the literary world, their popularity makes us question who has the power to constitute what is right and what is wrong if arts and literature are subjective to the reader? Debates about the validity of such poetry are futile in the context of this paper as postmodern critics have long established the primacy of the popular in cultural studies (Storey,5).

The ongoing coronavirus or Covid19 pandemic has effected not just an economic crisis but also a socio-cultural and psychological disruption with long term consequences (Brooks, 912). The selective fatality of the virus and its alarming levels of contagiousness has necessitated practicing of 'social-distancing' and an obsession with personal hygiene. In the age of medical and scientific advancements, the virus has taken us by complete surprise by the extent to which it has paralyzed human lives. The Black Death or the plague had brought about serious and permanent changes in European feudal society, but it was in the thirteenth 

can cause a similarly massive and permanent alteration to our socio-economic structure has given us a lot to think about. The psychological cost of social-distancing and quarantine has been immense (Rahman, Web). It has also forced many of us to slow down and reflect and churn out positivity almost compulsorily for the sheer necessity of going on. Perhaps this is what instigated the poems that are taken up in the following sections to go 'viral'. After all the healing effects of writing poems have been known for a long time (Carroll, Web).

In this age of virtual reality and 'viral marketing', 'going viral', ironically taking after the concept of viral transmissions of diseases, is considered to be a measure of success as it indicates the number of times it has been exchanged and circulated or perused through the internet and social media platforms. It is what an online presence aims to cultivate: the more the number of shares and posts likes and comments, the greater is the success of stakeholders of the content. Thereby, fulfilling the objective of advertisement, i.e. gaining exposure (Petrescu, 2). Likewise, anything that goes viral, whether it is a piece of news, an image, a cartoon, a quote or in this case, a poem, is taken note of; it is discussed or written about even in offline mediums. That is how a couple poems which went viral on the internet during countrywide coronavirus lockdowns got our attention. Despite the popularity of social-media poets, the two poems, 'Lockdown' and 'The First Lines of Emails I've Received While Quarantining' which are taken up for consideration here are not by any of these popular 'poets'. They were written by persons who had no ambition to professionalism or fame as poets and their writing was not embellished to be visually attractive post-card posts. Their poems became viral rather randomly wherein lies their significance, as that indicates the presence of the void in our culture that such poems fill. These poems were covered by mainstream and offline media despite them being long and not written in any aesthetically pleasing marketable format. For instance the poem titled 'Lockdown' by Irish priest, Brother Richard Hendrick which was broadcasted by the BBC Radio and covered by The Hindu and The Business Standard (Menon). It was posted by the priest as a Facebook post on March $13^{\text {th }}$ 2020 (Hendrick $)^{1}$. His original post has received more than nineteen thousand positive reactions and has been shared more than thirty-four thousand times (Staff, Web). The poem starts with a stirring note on natural renewal:

"Yes there is fear.

Yes there is isolation.

Yes there is panic buying.

Yes there is sickness.

Yes there is even death.

But,

\footnotetext{
${ }^{1}$ The poem was posted as a Facebook Status Update and was not published anywhere else. The number of likes and shares on this Facebook post has increased since the day it was cited.
} 
CODEN: LITIBR

Vol-2, Issue-1 (2 ${ }^{\text {nd }}$ July, 2020)

Page No: $44-53$

DOI: 10.47365/litinfinite.2.1.2020.44-53

Section: Article

They say that in Wuhan after so many years of noise

You can hear the birds again." (Hendrick, Web)

It continues for about forty more lines emphasizing the possibilities of positivity amid the dark uncertainty of the pandemic. In several places around the world, particularly in cities, there was remarkable improvement of the air quality (Goswami, Web). In India, many cities witnessed wild animals on their streets. Navi Mumbai saw hundreds of flamingos migrating to its wetlands, taking the cooped up urban residents by pleasant (S. Reporter). In some cities, even deer and leopards were seen. (Balakrishna, Web). Internationally, the absence of vehicular traffic on city roads reduced the amount of Nitrogen Dioxide in the air in Europe and Asia by forty percent improving the Air Quality Index (Monks, Web). Hence when this poet-priest writes:"They say that after just a few weeks of quiet/The sky is no longer thick with fumes/ But blue and grey and clear" (Hendrick, Web). It is not just an articulation of a wish or fancy hope but an actuality. This is what makes the poem remarkable in its hopefulness and realism. The list of kind actions the poet lists are not of his own making, but real ways in which humans across the world found themselves capable of kindness and resilience despite the ugliness surrounding them. The poem runs by juxtaposing each of the inevitable negative facts about these times such as social-isolation, panic-buying, fear with acts of warmth and generosity and with natural renewal. The gesture of Cuban doctors arriving in Italy to serve during the pandemic and the scene of Italians singing from their balconies to cheer up the neighbourhood during social isolation has warmed hearts as Italy was one of the worst affected countries during the pandemic for a while (Kearney, Web). Several E-journals and newspapers reported about acts of human solidarity and kindness (Foster, Web). Hence the following lines could not be truer:

"They say that in the streets of Assisi

People are singing to each other

Across the empty square

Keeping their windows open

So that those who are alone

May hear the sounds of family around them"(Hendricks, Web)

This is not the only poem that celebrates the recovery of the natural environment. An Economic Times article notes how the clean air and blue skies have made the digital poets start writing odes to nature and it author even hails this upsurge of nature-poetry on social media as post-pandemic poetry: "Struck by the revival of blue skies, clean air, clear light, birdsong, triggered by this unexpected hiatus, lakhs of awed 'digital poets' have been recording and posting their technology-aided parallels of the brilliant odes to nature of, say, Tagore or Tennyson." (Bureau, Web) Poetry inspired by nature in the Romantic age was a reaction to the onslaught of the agricultural revolution, rapid urbanization and the growth of industries. for Evans writes about the Romantic poets in these words: "They all had a deep interest in nature, not as a 
Litinfinite Journal

ISSN: 2582-0400 [Online]

CODEN: LITIBR

Vol-2, Issue-1 (2 ${ }^{\text {nd }}$ July, 2020)

Page No: $44-53$

DOI: 10.47365/litinfinite.2.1.2020.44-53

Section: Article

centre of beautiful scenes but as an informing and spiritual influence on life"(Evans, 66). Modern capitalism has continuously devastated natural ecosystems and disturbed the balance necessary to sustain the biosphere, accelerating climate change which is already wreaking havoc in many parts of the world (Park, Web).The surge of online poetry on nature and its restorative and balancing powers manifested by the pandemic need not imply a neo-romantic return to nature. But considering how nature's healing has been documented across various cities during this time, the popular Instapoets expressing the phenomenon can be said to be making a dent in terms of indicating one of the directions that contemporary poetry of this genre might be taking. The Poet Laureate Simon Armitage also penned a poem on the coronavirus lockdown which suggestively praises the beauty of natural landscapes during a phase of undisturbed quietness in his lines:

"Streams like necklaces,

Fan-tailed peacocks, painted elephants,

Embroidered bedspreads

Of meadows and hedges,

Bamboo forests and snow-hatted peaks,

Waterfalls, creeks,

The hieroglyphs of wide-winged cranes

And the glistening lotus flower after rain,

The air

Hypnotically see-through, rare..”(Armitage, Web)

The only difference between the previous viral poem and this one is the use of language. Understandably a smaller audience would be able to grasp the metaphors and references to myths or even decode his intricate word-image. Nor does Armitage's poem offer a lucid reminder of the paths to recovery and acceptance that are still open to us in a way that fills the reader with calm gratitude as in these concluding lines:

Wake to the choices you make as to how to live now.

Today, breathe.

Listen, behind the factory noises of your panic

The birds are singing again

The sky is clearing,

Spring is coming,

And we are always encompassed by Love.

Open the windows of your soul

And though you may not be able

to touch across the empty square,

Sing (Hendrick, lines 46-56)

But the fact that even the poet laureate speaks of natural renewal and beauty, and of recovering and growing during the lockdown and uncertainty of life, affirms the definite tendency of nature-poetry making a come-back, at least in a few circles. 
The West Virginian English teacher, Jessica Salfia's 'As You Know Many People are Struggling' or 'The First Lines of Emails I've Received While Quarantining' was widely covered by most major international newspapers like The Times of India and The Guardian (Cain). In less than a day, Salfia's poem was shared eighty-three thousand times and by twenty-three thousand Twitter accounts ${ }^{2}$ @jessica_salfia). It got shared over a million times on Twitter alone. The poem has thirty-six lines with the refrain: "As you know, many people are struggling". It is noteworthy because of the interesting turn it takes towards a whole new genre of internet-poetry. The same article that covers her poem mentions that it inspired many more people to pen poetry from emails they received, for instance, one made by a student nurse by stringing lines from emails she got from her college with the encouraging refrain: "As we know, we will get through this"(The Guardian). The poem was constructed entirely by putting together the first lines of emails she received during the quarantine period yet it makes perfect sense. It was not even a century ago that a Modernist movement known as Dadaism with proponents like Marcel Duchamp and Tristan Tzara made a quite a few ripples in the world of aesthetics. The movement was about overturning the bourgeoisie norms of art and was often defiantly 'anti-art' (Hopkins,1).It often relied on the bizarre, nonsense, or even humour to express this kind of anti-art or anti-institutionalism. The movement was in reaction to the rise of capitalism, war and destruction. The proponents celebrated luck instead of calculated intent to create art, by adopting free-play when it comes to creating art or poetry. Dadaism also employs new media and visual or performative mediums for example, Jean Arp explored the art of collage and the potential for randomness in its creation. (What is Dadaism, Dada Art, or a Dadaist?).Thus, although the present poem is not nonsensical, it can be said to bear clear resonance with Dadaist poetry. In fact, despite the juxtaposition of lines from different emails she luckily received, made it sound coherent and meaningful right from the first stanza itself:

"In these uncertain times

As we navigate the new normal

Are you willing to share your ideas and solutions?

As you know many people are struggling. (Salfia, Web)

It strikes a note because email is one of the means of communication that lockdown and countrywide quarantine like conditions allowed. The opening lines of emails are normally always salutary and positive, but the 'poem' manages to contrast the positive and the negative bringing out the possible silver linings in the situation. What makes it engaging is it asks people to participate in thinking of ways in which circumstances can be made tolerable; it also consoles them for failing to keep in their best forms. Almost every stanza sustains our interest despite how drab lines appear in emails:

"I know you are up against it:

The digital landscape

\footnotetext{
2 This information has been taken from the newspaper articles cited earlier. The poem was initially published by Jessica Salfia as a Twitter post. It has since received more 'likes' and comments than the number given here. It is not published in any print medium. The post can be checked out at <https://twitter.com/jessica_salfia/status/1249000027198033922?lang=en>
} 
Litinfinite Journal

ISSN: 2582-0400 [Online]

CODEN: LITIBR

Vol-2, Issue-1 ( $\left.2^{\text {nd }} J u l y, 2020\right)$

Page No: $44-53$

DOI: 10.47365/litinfinite.2.1.2020.44-53

Section: Article

We share your concerns.

As you know, many people are struggling”(Salfia, Web)

The verses also critique modern capitalism and advertisement culture as in these lines:

We hope this note finds you and your family safe

We've never seen anything like this before

Here are 25 distance learning tips

As you know many people are struggling"(Salfia, Web)

Or as in the lines like the following which were probably sent from some delivery-service managing company:

"Count your blessings. Share your blessings

Get free curb side pick-up or ship to your house!

Chicken! Lemon! Artichokes!

As you know, many people are struggling"(Salfia, Web)

The 'poem' attempts to satirize corporate opportunism by highlighting capitalist clichés. Sometimes the tone gets comforting and urges one to forgive oneself for self-indulgence and for not being in the best form during the lockdown, subtly encouraging the reader to continue shopping for food items as in the following stanza:

"Feeling Fiesta today? Happy Taco Tuesday!

Calories don't count during pandemic

Grocers report flour shortages as more people are baking than ever!

As you know many people are struggling" (Salfia, Web)

In an interview with the CBC Radio, the creator said that though the poem might have gotten viral because in an extreme situation like this, people turn to poetry for comfort but many marketing managers also thanked her the poetry saying it showed them what they were doing wrong(Chattopadhyay, Web). She says in the same interview that the lines she used in the poem came from all kinds of companies like clothing brands, educational institutes and organizations, some of which she admired like the 'New York cooking'. She says that initially when the lockdown period had just started, the companies tried to sound sincere and genuine, but as time passed, they started to capitalise the situation which came across in poor taste especially with the adage "As you know many people are struggling." Hence from these two examples of social-media poetry by ordinary people who had no aim of becoming highselling Instagram poets it is clear that there is a definite trend towards anti-capitalistic poems on nature, healing and self-love, especially because the current crisis has revealed so many fault-lines of modern socio-economic systems.

The idea behind focusing on these two viral poems which are not by any 'instapoet' was to show that the thirst for poetry is far from over. A New York Times article titled: 'What Do the Humanities Do in a Crisis' says that this is precisely the time for the humanities to 
Litinfinite Journal

ISSN: 2582-0400 [Online]

CODEN: LITIBR

Vol-2, Issue-1 ( $\left.2^{\text {nd }} J u l y, 2020\right)$

Page No: $44-53$

DOI: 10.47365/litinfinite.2.1.2020.44-53

Section: Article

flourish as it is only when humankind is living under the shadow of death with no real connection between one another, that we can appreciate life and strive for meaning (Callard, Web). The same can be said about poetry as it should be in a better position to offer a way out of anxiety and numbness during these trying times.

\section{Works Cited}

i. $\quad$ "American teacher constructs poignant poem out of emails." Times of India 14 Apr. 2020: $\mathrm{n}$. pag. Web. 30 May 2020. <https://timesofindia.indiatimes.com/life-

style/books/features/american-teacher-constructs-poignant-poem-out-ofemails/articleshow/75140867.cms>.

ii. $\quad$ "Finding the Words to Say It: The Healing Power of Poetry." Evidence-based Complementary and Alternative Medicine 2.2 (2005): n. pag. Web. 30 May 2020.

<https://www.researchgate.net/publication/7803866_Finding_the_Words_to_Say_It_The_He aling_Power_of_Poetry>.

iii. $\quad$ "Large number of flamingos flock to Navi Mumbai. Viral video." India Today 20 Apr. 2020: n. pag. Web. 30 May 2020. <https://www.indiatoday.in/trending-news/story/large-number-offlamingos-flock-to-navi-mumbai-viral-video-1668926-2020-04-

20\#: :text=The $\% 20$ flamingos\%20were $\% 20$ spotted $\% 20$ at,for $\% 20$ foraging $\% 20 \mathrm{in} \% 20$ the $\% 20$ wetlands>.

iv. "Post-pandemic poetry: As world comes to a screeching halt, 'digital poets' are writing odes to nature." The Economic Times 7 Apr. 2020: n. pag. Web. 30 May 2020.

$<$ https://economictimes.indiatimes.com/magazines/panache/post-pandemic-poetry-as-worldcomes-to-a-screeching-halt-digital-poets-are-writing-odes-to-nature/articleshow/> .

v. $\quad$ "Priest in Ireland pens touching poem about coronavirus lockdown." Irish Central 22 May 2020: n. pag. Web. 30 May 2020. <https://www.irishcentral.com/culture/coronaviruslockdown-poem>.

vi. $\quad$ "Watch: Cuban doctors arrive in Italy to fight coronavirus, get a loud welcome." India Today 23 Mar. 2020: n. pag. Web. 30 May 2020. <https://www.indiatoday.in/trendingnews/story/watch-cuban-doctors-arrive-in-italy-to-fight-coronavirus-get-a-loud-welcome1658771-2020-03-23>.

vii. $\quad$ "What is Dadaism, Dada Art, or a Dadaist?" Artland Magazine. artland.com, n.d. Web. 30 May 2020. <https://magazine.artland.com/what-is-dadaism/>.

viii. Balakrishna, Medabayani. "Animals Take to Streets as Covid-19 Lockdown Keeps Pilgrims away from Tirupati." News 18. News 18 India, 24 Apr. 2020. Web. 30 May 2020.

<https://www.news 18.com/news/india/animals-take-to-streets-as-covid-19-lockdown-keepspilgrims-away-from-tirupati-2591595.html>.

ix. Brooks, Samantha K., et al. "The psychological impact of quarantine and how to reduce it: rapid review of the evidence." The Lancet 395.10227 (2020): 912-920. Web. 30 May 2020. $<$ https://www.thelancet.com/journals/lancet/article/PIIS0140-6736(20)30460-8/>.

x. $\quad$ Cain, Sian. "Poem constructed from emails received during quarantine goes viral." The Guardian 12 Apr. 2020: n. pag. Web. 30 May 2020.

<https://www.theguardian.com/books/2020/apr/12/poem-constructed-from-emails-duringquarantine-goes-viral>.

xi. Callard, Agnes. "What Do the Humanities Do in a Crisis?" The New Yorker 11 Apr. 2020: n. pag. Web. 30 May 2020. <https://www.newyorker.com/culture/annals-of-inquiry/what-dothe-humanities-do-in-a-crisis $>$.

xii. $\quad$ Carroll, Robert. "Finding the Words to Say It: The Healing Power of Poetry." Evidence-based Complementary and Alternative Medicine 2.2 (n.d.): 161-172. Web. 30 May 2020. 
Litinfinite Journal

ISSN: 2582-0400 [Online]

CODEN: LITIBR

Vol-2, Issue-1 ( $\left.2^{\text {nd }} J u l y, 2020\right)$

Page No: $44-53$

DOI: 10.47365/litinfinite.2.1.2020.44-53

Section: Article

<https://www.researchgate.net/publication/7803866_Finding_the_Words_to_Say_It_The_He aling_Power_of_Poetry>.

xiii. $\quad$ Cyril, Grace. "Verses in the time of coronavirus pandemic: Poetry takes the virtual route."

Hindustan Times [Delhi] 1 May 2020: n. pag. Web. 30 May 2020.

$<$ https://www.hindustantimes.com/art-and-culture/verses-in-the-time-of-coronaviruspandemic-poetry-takes-the-virtual-route/story-w7Sc9s4U2mjmz7OdT6i50N.html>.

xiv. $\quad$ Epstein, Joseph. "Who Killed Poetry." Commentary Magazine Aug. 1998: n. pag. Web. 30 May 2020. <https://www.commentarymagazine.com/articles/joseph-epstein/who-killedpoetry/>.

xv. $\quad$ Evans, Ifor. "The Romantic Poets." A Short History of English Literature. 4th ed.

Penguin, 1976. 66-90. Print.

xvi. Flood, Alison. "Lockdown: Simon Armitage writes poem about coronavirus outbreak." The Guardian 21 Mar. 2020: n. pag. Web. 30 May 2020.

$<$ https://www.theguardian.com/books/2020/mar/21/lockdown-simon-armitage-writes-poemabout-coronavirus-outbreak>.

xvii. Foster, Peter, et al. "Locked-down Europeans fight coronavirus with solidarity, kindness and dancing." The Telegraph 16 Mar. 2020: n. pag. Web. 30 May 2020.

$<$ https://www.telegraph.co.uk/news/2020/03/16/locked-down-europeans-fight-coronavirussolidarity-kindness/>.

xviii. Garg, Ruchira. "Delhi-based cop pens poetry to spread awareness on corona." Hindustan Times [New Delhi] 16 Apr. 2020: n. pag. Web. 30 May 2020.

$<$ https://www.hindustantimes.com/coronavirus-crisis/delhi-based-cop-pens-poetry-to-spreadawareness-on-corona/story-1JaZEa3iDJ0j8xoxQ69O0K.html>.

xix. Gioia, Diana. "Can Poetry Matter?" The Atlantic 1 May 1991: n. pag. Web. 30 May 2020. <https://www.theatlantic.com/magazine/archive/1991/05/can-poetry-matter>.

xx. Goswami, Kajari. "Covid-19: 4 unbelievable environmental changes seen in India since lockdown." India Today 2 May 2020: n. pag. Web. 30 May 2020.

$<$ https://www.indiatoday.in/education-today/gk-current-affairs/story/covid-19-4-vitalenvironmental-changes-evidenced-in-india-since-lockdown-1673726-2020-05-02>.

xxi. $\quad$ Hendrick, Richard. "Lockdown." Facebook, 13 Mar. 2020. Web. 30 May 2020.

<https://www.facebook.com/BroRichard/posts/10158060660454328>.

xxii. Hopkins, David. Dada and Surrealism: A Very Short Introduction. New York: Oxford UP, 2004. Print.

xxiii. James, Tom. "BBC - History - British History in Depth: Black Death: The Lasting Impact." BBC - History. BBC, 17 Feb. 2011. Web. 30 May 2020.

<http://www.bbc.co.uk/history/british/middle_ages/black_impact_01.shtml>.

xxiv. $\quad$ Kaur, Rupi. "Instagram Photo." Photograph. Instagram, 4 Feb. 2019. Web. 30 May 2020. $<$ https://www.instagram.com/p/BtcYE9YHVrx/>.

xxv. Kaur, Rupi. "Rupi Kaur: 'There was no market for poetry about trauma, abuse and healing'." Interview by Ashifa Kassam. The Guardian 26 Aug. 2016: n. pag. Web. 30 May 2020. <https://www.theguardian.com/books/2016/aug/26/rupi-kaur-poetry-canada-instagrambanned-photo>.

xxvi. Kearney, Christine. "Italians sing patriotic songs from their balconies during coronavirus lockdown." The Guardian 14 Mar. 2020: n. pag. Web. 30 May 2020.

$<$ https://www.theguardian.com/world/2020/mar/14/italians-sing-patriotic-songs-from-theirbalconies-during-coronavirus-lockdown>.

xxvii. Leszkiewicz, Anna. "Why are we so worried about "Instapoetry"?" Nes Statesman 6 Mar. 2019: n. pag. Web. 30 May 2020. 
Litinfinite Journal

ISSN: 2582-0400 [Online]

CODEN: LITIBR

Vol-2, Issue-1 (2 ${ }^{\text {nd }}$ July, 2020)

Page No: 44-53

DOI: 10.47365/litinfinite.2.1.2020.44-53

Section: Article

<https://www.newstatesman.com/culture/books/2019/03/instapoetry-rupi-kaur-genre-rmdrake-rh-sin-atticus-hollie-monish>.

xxviii. $\quad$ Londono, Alex. "Girl pens heartfelt poem for NHS workers." NHS Barts Health NHS Trust. NHS Barts Health NHS Trust, 7 Apr. 2020. Web. 30 May 2020.

<https://www.bartshealth.nhs.uk/news/girl-pens-heartfelt-poem-for-nhs-workers-7847>.

xxix. Lovelace, Berkeley. "The coronavirus may be deadlier than the 1918 flu: Here's how it stacks up to other pandemics." Health and Science. CNBC, 27 Mar. 2020. Web. 30 May 2020. <https://www.cnbc.com/2020/03/26/coronavirus-may-be-deadlier-than-1918-flu-heres-howit-stacks-up-to-other-pandemics.html>.

xxx. $\quad$ Menon, Anasuya. "Poetry in the times of Covid-19." The Hindu 25 Mar. 2020: n. pag. Web. 30 May 2020. <https://www.thehindu.com/entertainment/poetry-in-the-times-of-covid19/article31163319.ece>.

xxxi. Modi, Chintan G. "The global health crisis has spawned reams of poignant poetry worldwide." Business Standard 27 Mar. 2020: n. pag. Web. 30 May 2020.

$<$ https://www.business-standard.com/article/current-affairs/the-global-health-crisis-hasspawned-reams-of-poignant-poetry-worldwide-120032701531_1.html>.

xxxii. Monks, Paul. Here's how lockdowns have improved air quality around the world. World Economic Forum, 2020. Web. 30 May 2020.

<https://www.weforum.org/agenda/2020/04/coronavirus-lockdowns-air-pollution>.

xxxiii. $\quad$ Mzezewa, Tariro. "Rupi Kaur Is Kicking Down the Doors of Publishing." The New York Times 5 Oct. 2017: n. pag. Web. 30 May 2020.

$<$ https://www.nytimes.com/2017/10/05/fashion/rupi-kaur-poetry-the-sun-and-herflowers.html>.

xxxiv. $\quad$ Park, Jonathan T. "Climate Change and Capitalism." Consilience: The Journal of Sustainable Development 14.2 (2015): 189-206. Web. 30 May 2020.

<https://www.jstor.org/stable/26188749>.

xxxv. $\quad$ Petrescu, Maria. "Viral Marketing." Viral Marketing and Social Networks. New York: Business Expert Press, 2014. 1-8. PDF File.

xxxvi. Rahman, Azera P. "Isolation and mental health: the psychological impact of lockdown." The Hindu 4 Apr. 2020: n. pag. Web. 30 May 2020. <https://www.thehindu.com/society/isolationand-mental-health-the-psychological-impact-of-lockdown/article31237956.ece>.

xxxvii. $\quad$ Salfia, Jessica. "'In these uncertain times': Teacher crafts poem out of quarantine emails." Interview by Piya Chattopadhyay. CBC Radio, 14 Apr. 2020. Web. 30 May 2020. $<$ https://www.cbc.ca/radio/asithappens/as-it-happens-tuesday-edition-1.5531704/in-theseuncertain-times-teacher-crafts-poem-out-of-quarantine-emails-> .

xxxviii. $\quad$ Salfia, Jessica. "Twitter." This poem is called "First lines of emails I've received while quarantining.". Twitter, 11 Apr. 2020. Web. 30 May 2020.

<https://twitter.com/jessica_salfia/status/1249000027198033922?lang=en>.

xxxix. Storey, John. "What is Popular Culture." Cultural Theory and Popular Culture: An Introduction. 5th ed. London: Pearson Education, 2006. 1-14. Print.

xl. Wallersteiner, Imogen. "The Rise of the Insta-Poet." Isis 25 July 2019: n. pag. Web. 30 May 2020. <https://isismagazine.org.uk/2019/07/the-rise-of-the-insta-poet/>.

xli. Wilcoz, Lauren. "Is poetry dead? Or, in the age of the Internet, does it offer us what nothing else can?" The Washington Post 13 Jan. 2012: n. pag. Web. 30 May 2020.

$<$ https://www.washingtonpost.com/lifestyle/magazine/rhyme-and-reason-in-the-age-oftwitter-internet-dependency-reality-tv-poetry-still-offers-us-what-nothing-elsecan/2011/10/27/gIQAEghXtP_story.html>. 